\title{
Raynaud's phenomenon and antiphospholipid antibodies in systemic lupus erythematosus: is there an association?
}

\author{
D Caccavo, F Del Porto, P Garzia, A P Mitterhofer, S Galluzzo, A Rigon, M Vadacca, \\ M F Navajas, A Amoroso, A Afeltra
}

Objective: To evaluate the association of $\lg G$ and $\lg M$ antibodies directed against different negatively charged phospholipids (that is, anticardiolipin (aCL), antiphosphatidylinositol, antiphosphatidylserine, and antiphosphatidic acid) and anti- $\beta_{2}$-glycoprotein I (a $\beta_{2}$ GPI), with Raynaud's phenomenon in patients with systemic lupus erythematosus (SLE).

Methods: Ninety three patients with SLE (81 female), 40 with and 53 without Raynaud's phenomenon, were included in the study. $\lg G$ and $\lg M$ antiphospholipid antibodies and $a \beta_{2}$ GPI were determined by enzyme linked immunosorbent assay (ELISA).

Results: Fifty patients (54\%) were positive for lgG and/or $\lg M$ antibodies to one or more phospholipid antigens or to $\beta_{2}$ GPI. The prevalence of all autoantibodies evaluated, either $\lg G$ or $\lg M$, was higher in patients without than in those with Raynaud's phenomenon. A negative association was found between $\operatorname{lgG} \mathrm{aCL}$ and Raynaud's phenomenon $(p=0.038)$, whereas autoantibodies other than aCL were not significantly associated with Raynaud's phenomenon.

Conclusion: Our results demonstrate no positive association between antiphospholipid antibodies and Raynaud's phenomenon in SLE and indicate that measurement of antinegatively charged phospholipid antibodies other than $\mathrm{aCl}$ is not useful as a serological marker predictive for Raynaud's phenomenon.

$\mathrm{R}$ aynaud's phenomenon (RP) is a disorder characterised by recurrent reversible vasospasm of fingers and toes often induced by exposure to cold. ${ }^{1}$ It is classified as primary or secondary, according to the absence or the presence of a known associated disease, respectively. Secondary RP is frequently present in patients affected by connective tissue diseases (CTD), including systemic sclerosis, systemic lupus erythematosus (SLE), Sjögren's syndrome, dermatomyositis or polymyositis, and rheumatoid arthritis.

Antiphospholipid antibodies (aPL) are autoantibodies directed against negatively charged phospholipids and their presence is significantly associated with arterial and/or venous thrombosis and recurrent fetal loss, the so-called antiphospholipid syndrome. ${ }^{2}$ Antiphospholipid antibodies have also been found to be associated, to a lesser extent, with other clinical manifestations. ${ }^{2}$ Besides anticardiolipin antibodies $(\mathrm{aCL})$, which have been the most extensively studied aPL, the prevalence and clinical relevance of autoantibodies against other negatively charged phospholipids, such as antiphosphatidylinositol (aPI), antiphosphatidylserine (aPS), antiphosphatidic acid (aPA), and antibodies to $\beta_{2}$-glycoprotein I $\left(\mathrm{a} \beta_{2} \mathrm{GPI}\right)$, a plasma protein with anticoagulant activities, have been evaluated in recent years. ${ }^{4-8}$
Only a few studies have been performed to examine the association between RP and aCL, and conflicting results have been reported..$^{9-13}$ On the other hand, no data are available on the association between RP and different aPL, other than aCL.

Therefore, this study aimed at analysing the association between RP and aCL, aPI, aPS, aPA, and $a \beta_{2}$ GPI in patients affected by SLE.

\section{PATIENTS AND METHODS}

Ninety three patients, fulfilling four or more criteria of the American College of Rheumatology for the classification of SLE, updated according to Hochberg, ${ }^{14}{ }^{15}$ were included in the study. Patients were divided into two groups according to the presence (SLE cases) or the absence (SLE controls) of RP. To determine the cut off level of aPL, serum samples from 50 healthy donors matched for sex and age, who showed normal coagulation assays and negative serological tests for syphilis, were used. Sera were stored at $-80^{\circ} \mathrm{C}$ until used. Samples were coded and investigators performing the assays were unaware of the presence or absence of RP.

\section{Antiphospholipid antibody quantification}

The measurement and characterisation of IgG and IgM aPL were performed by enzyme linked immunosorbent assay (ELISA) using commercially available kits (ORGenTecDiagnostika GmbH, Mainz, Germany). In brief, serum samples diluted 1:100 were first screened in microplates coated with a mixture of negatively charged phospholipidsthat is, cardiolipin, phosphatidylinositol, phosphatidylserine, and phosphatidic acid (AntiPhospholipid Screen, ORGenTecDiagnostika). The wells were saturated with purified human $\beta_{2}$ GPI as cofactor for antibody binding. All samples were assayed in duplicate. Combined IgG and IgM calibrators ranging from 0 to 120 and from 0 to 80 arbitrary $\mathrm{U} / \mathrm{ml}$, respectively, were supplied by the manufacturer, and a standard curve was established. The assay system was calibrated against the internationally recognised aCL reference sera from EN Harris, Lousville, USA. Values $\geqslant 10$ arbitrary $\mathrm{U} / \mathrm{ml}$ (a value higher than the 99th centile of the control sera for both IgG and IgM antibodies) were considered positive. Sera positive in this preliminary screening were tested against single phospholipid antigens coated in the presence of $\beta_{2}$ GPI as cofactor, or against purified $\beta_{2}$ GPI which was coated on high binding $\gamma$ irradiated wells. Sera showing optical density values exceeding the detection limit of the standard curve were further diluted and assayed.

Abbreviations: $a \beta_{2} \mathrm{GPI}$, anti- $\beta_{2}-$ glycoprotein I antibodies; $\mathrm{aCL}$, anticardiolipin antibodies; aPA, antiphosphatidic acid antibodies; aPI, antiphosphatidylinositol antibodies; aPL, antiphospholipid antibodies; aPS, antiphosphatidylserine antibodies; CTD, connective tissue diseases; RP, Raynaud's phenomenon; SLE, systemic lupus erythematosus 
Table 1 Comparison of demographic and salient immunological data for Raynaud's phenomenon positive and Raynaud's phenomenon negative patients

\begin{tabular}{llll}
\hline & $\begin{array}{l}\text { Raynaud+ } \\
(\mathrm{n}=40)\end{array}$ & $\begin{array}{l}\text { Raynaud- } \\
(\mathrm{n}=53)\end{array}$ & $\mathrm{p}$ Value \\
\hline Number & 40 & 53 & \\
Age (years), mean (SD) & $38.5(12.9)$ & $38.5(10.1)$ & $\mathrm{NS}$ \\
Women, No (\%) & $36(90)$ & $45(85)$ & $\mathrm{NS}$ \\
Age of disease onset (years), mean (SD) & $30.6(11.4)$ & $28.3(9.9)$ & $\mathrm{NS}$ \\
Disease duration (years), mean (SD) & $7.4(5.6)$ & $10.2(8.8)$ & $\mathrm{NS}$ \\
ANA+*, No (\%) & $40(100)$ & $53(100)$ & $\mathrm{NS}$ \\
Anti-dsDNA+†, No (\%) & $19(48)$ & $23(43)$ & NS \\
Corticosteroids, No (\%) & $40(100)$ & $53(100)$ & NS \\
Other immunosuppressive drugsł, No (\%) & $12(30)$ & $18(34)$ & NS \\
\hline
\end{tabular}

*ANA were determined by indirect immunofluorescence on $\mathrm{HEp}-2$ cell line; †anti-dsDNA were determined by indirect immunofluorescence on Crithidia luciliae; łother immunosuppressive drugs were cyclosporin A, azathioprine, or methotrexate; §non-significant.

Table 2 Antiphospholipid antibody (aPL) in the whole group of patients with SLE ( $n=93$ ): prevalence, antigen specificity, and isotype distribution

\begin{tabular}{lllll}
\hline aPL* & $\begin{array}{l}\text { IgG } \\
\text { No (\%) }\end{array}$ & $\begin{array}{l}\text { IgM } \\
\text { No (\%) }\end{array}$ & $\begin{array}{l}\text { IgG and IgM } \\
\text { No (\%) }\end{array}$ & $\begin{array}{l}\text { Total } \\
\text { (IgG and/or IgM) } \\
\text { No (\%) }\end{array}$ \\
\hline $\mathrm{aCL}$ & $36(39)$ & $1(1)$ & $13(14)$ & $50(54)$ \\
$\mathrm{aPI}$ & $15(16)$ & $4(4)$ & $14(15)$ & $33(35)$ \\
$\mathrm{aPS}$ & $22(24)$ & $2(2)$ & $13(14)$ & $37(40)$ \\
$\mathrm{aPA}$ & $20(22)$ & $5(5)$ & $13(14)$ & $38(41)$ \\
$\mathrm{a} \beta_{2} \mathrm{GPI}$ & $11(12)$ & $3(3)$ & $12(13)$ & $26(28)$ \\
\hline
\end{tabular}

*All aPL were determined by ELISA, values $\geqslant 10$ arbitrary $\mathrm{U} / \mathrm{ml}$ were considered positive.

\section{Statistical analysis}

Two-group comparisons were analysed by Fisher's exact test (two tailed) for categorical variables and by Student's $t$ test or Mann-Whitney $U$ test for continuous variables according to Gaussian or non-Gaussian distribution, respectively. Values of $\mathrm{p}<0.05$ were considered to be significant.

\section{RESULTS}

The study group comprised 93 patients, of whom 81 were women. Their mean age was 38.5 (SD 11.3 years; range 17-69). Forty patients (43\%) had RP never complicated by digital necrosis. Table 1 shows the demographic and salient immunological features of the two patient groups. No significant differences in age, sex distribution, disease duration, presence of antinuclear antibodies and anti-dsDNA antibodies, and treatment were present between groups.

Table 2 shows the prevalence, antigen specificity, and isotype distribution of aPL in the total study group.

\section{Association between aPL and Raynaud's phenomenon}

Table 3 compares the prevalence of different aPL in patients with and without RP. Overall, RP was observed in a higher percentage of aPL negative than in aPL positive patients. This finding was observed, to a different extent, for either IgG or IgM aCL, aPI, aPS, aPA, and a $\beta_{2}$ GPI. However, the negative association between aPL and RP reached significance $(p=0.038)$ only for IgG aCL. No significant difference was shown between the median titre of aPL between patients with and without RP, irrespective of antigen specificity and isotype (data not shown).

To determine whether the degree of aCL positivity differed significantly between RP positive and RP negative patients, aCL positive patients were subdivided into two groupsnamely, patients with low $(<20 \mathrm{U} / \mathrm{ml})$ and patients with medium-high ( $\geqslant 20 \mathrm{U} / \mathrm{ml}$ ) antibody titre. Twenty eight of 50 aCL positive patients $(56 \%)$ showed medium-high antibody titre. The distribution of patients with medium-high aCL titre between RP positive and RP negative patients was 10/40 (25\%) among RP positive and 18/53 (34\%) among RP negative patients, and the difference was not significant $(p=0.37)$.

\begin{tabular}{|c|c|c|c|c|c|c|c|c|c|}
\hline \multirow[b]{2}{*}{ aPL* } & \multicolumn{3}{|c|}{ Total (IgG and/or lg $M$ ) } & \multicolumn{3}{|l|}{$\lg G$} & \multicolumn{3}{|l|}{$\lg M$} \\
\hline & No & $\begin{array}{l}\text { Raynaud+ } \\
\text { No }(\%)\end{array}$ & $\mathrm{p}$ Value & No & $\begin{array}{l}\text { Raynaud+ } \\
\text { No (\%) }\end{array}$ & $\mathrm{p}$ Value & No & $\begin{array}{l}\text { Raynaud+ } \\
\text { No (\%) }\end{array}$ & $\mathrm{p}$ Value \\
\hline $\begin{array}{l}\mathrm{aCl}+ \\
\mathrm{aCl}-\end{array}$ & $\begin{array}{l}50 \\
43\end{array}$ & $\begin{array}{l}17(34) \\
23(53)\end{array}$ & 0.06 & $\begin{array}{l}49 \\
44\end{array}$ & $\begin{array}{l}16(33) \\
24(55)\end{array}$ & $0.038 \ddagger$ & $\begin{array}{l}14 \\
79\end{array}$ & $\begin{array}{l}4(29) \\
36(46)\end{array}$ & 0.38 \\
\hline $\begin{array}{l}\text { aPl+ } \\
\text { aPl- }\end{array}$ & $\begin{array}{l}33 \\
60\end{array}$ & $\begin{array}{l}12(36) \\
28(47)\end{array}$ & 0.38 & $\begin{array}{l}29 \\
64\end{array}$ & $\begin{array}{l}9(31) \\
31(48)\end{array}$ & 0.17 & $\begin{array}{l}18 \\
75\end{array}$ & $\begin{array}{l}8(44) \\
32(43)\end{array}$ & 1 \\
\hline $\begin{array}{l}\text { aPS+ } \\
\text { aPS- }\end{array}$ & $\begin{array}{l}37 \\
56\end{array}$ & $\begin{array}{l}13(35) \\
27(48)\end{array}$ & 0.28 & $\begin{array}{l}35 \\
58\end{array}$ & $\begin{array}{l}12(34) \\
28(48)\end{array}$ & 0.2 & $\begin{array}{l}15 \\
78\end{array}$ & $\begin{array}{l}5(33) \\
35(45)\end{array}$ & 0.57 \\
\hline $\begin{array}{l}\text { aPA+ } \\
\text { aPA- }\end{array}$ & $\begin{array}{l}38 \\
55\end{array}$ & $\begin{array}{l}13(34) \\
27(49)\end{array}$ & 0.2 & $\begin{array}{l}33 \\
60\end{array}$ & $\begin{array}{l}10(30) \\
30(50)\end{array}$ & 0.08 & $\begin{array}{l}18 \\
75\end{array}$ & $\begin{array}{l}6(33) \\
34(45)\end{array}$ & 0.43 \\
\hline $\begin{array}{l}\mathrm{a} \beta_{2} \mathrm{GPI}_{+} \\
\mathrm{a}_{2} \mathrm{GPI}_{+}\end{array}$ & $\begin{array}{l}26 \\
67\end{array}$ & $\begin{array}{l}9(35) \\
31(46)\end{array}$ & 0.35 & $\begin{array}{l}23 \\
70\end{array}$ & $\begin{array}{l}8(35) \\
32(46)\end{array}$ & 0.46 & $\begin{array}{l}15 \\
78\end{array}$ & $\begin{array}{l}5(33) \\
35(45)\end{array}$ & 0.57 \\
\hline
\end{tabular}




\section{DISCUSSION}

In this study we provide evidence that secondary RP is not positively associated with the presence of aPL in patients with SLE and we found a significant negative association between IgG aCL and RP. The results so far reported on the association between RP and aPL are contradictory, and this could be due, at least in part, to the different study groups evaluated in these investigations.

Vayssairat et al found a significantly higher prevalence of aCL in patients with RP than in healthy controls, especially in patients with CTD. 'However, because the prevalence of either aPL or RP is significantly higher in patients with CTD than in the normal population this finding is not surprising. On the other hand, in a case-control study limited to patients with clinical disorders such as thromboses, repeated abortions, thrombocytopenia without SLE, a significant positive association was reported between RP and aCL. ${ }^{10}$ However, it should be pointed out that this last study was performed on a relatively small number of patients.

By contrast, in a cooperative study conducted on a large number of patients with different CTD, also including 165 patients with undifferentiated CTD, a negative association between the presence of aCL and RP was found. ${ }^{11}$ This finding is in agreement with our results, even though it is hard to provide a possible explanation for this negative association. On the other hand, it should be pointed out that no significant association was observed in our study when the comparison was restricted to patients with a medium-high aCL titre. Another group of investigators evaluated the presence of aCL in patients affected by primary or secondary RP and found that, among 17 patients with SLE and RP, 7 (41\%) were aCL positive. ${ }^{12}$ Of note, this percentage is almost the same found in our study, where 17/40 (43\%) patients with SLE and RP showed aCL positivity. Finally, Bongard et al demonstrated a relationship between aCL and nailfold capillary changes in patients with SLE, but they failed to find an association between aCL and RP. ${ }^{13}$

Our further objective was to investigate a putative association between RP and aPL directed against other negatively charged phospholipids or $\beta_{2}$ GPI, because in recent years conflicting results have been reported on either the clinical relevance or clinical associations of these autoantibodies. ${ }^{78}$ We found IgG and/or IgM aPI, aPS, aPA, and a $\beta_{2}$ GPI in a lower percentage of patients in comparison with aCL and we recorded no significant association between RP and these different aPL or $\mathrm{a} \beta_{2}$ GPI.

In our opinion, the lack of association between aPL and RP is not surprising because vasospasm of the small muscular arteries and arterioles of the digits and not thrombosis is responsible for the syndrome. However, thrombotic events may complicate severe forms with sustained vasospasm, and patients unresponsive to conventional vasodilator treatment can be successfully treated with long term anticoagulation. ${ }^{1}$
In conclusion, our results, obtained in an adequate number of patients, argue against a positive association between RP and antibodies directed against negatively charged phospholipids or $\beta_{2}$ GPI, at least in SLE. The importance of the negative association between IgG aCL and RP, if any, needs to be confirmed in a larger number of patients.

\section{Authors' affiliations}

D Caccavo, Department of Clinical Medicine, Immunology, and Infectious Diseases, University of Bari, Bari, Italy

F Del Porto, A P Mitterhofer, S Galluzzo, A Amoroso, Department of Clinical Medicine, University La Sapienza, Rome, Italy P Garzia, A Rigon, M Vadacca, M F Navajas, A Afeltra, University Campus Bio-Medico, Rome, Italy

Correspondence to: Professor A Afeltra, University Campus Bio-Medico, Viale E Longoni 83, 00155 Rome, Italy; a.afeltra@unicampus.it

Accepted 11 February 2003

\section{REFERENCES}

1 Block JA, Sequeira W. Raynaud's phenomenon. Lancet 2001;357:2042-8

2 Huges GRV. The anticardiolipin syndrome. Clin Exp Rheumato 1985;3:285-6.

3 Asherson RA, Cervera R. 'Primary', 'secondary' and other variants of the antiphospholipid syndrome. Lupus 1994;3:293-8.

4 Carreras LO, Ricardo R, Forastiero RR, Martinuzzo ME. Which are the best biological markers of the antiphospholipid syndrome? J Autoimmun 2000; 15:163-72.

5 Viard JP, Amoura Z, Bach JF. Association of anti- $\beta 2$-glycoprotein I antibodies with lupus-type circulating anticoagulant and thrombosis in systemic lupus erythematosus. Am J Med 1992;93:181-6.

6 Toschi V, Motta A, Castelli C, Gibelli S, Cimminiello C, Molaro GL, et al. Prevalence and clinical significance of antiphospholipid antibodies to noncardiolipin antigens in systemic lupus erythematosus. Haemostasis 1993:23:275-83.

7 Lopez-Soto A, Cervera R, Font J, Bove A, Reverter JC, Munoz FJ, et al. Isotype distribution and clinical significance of antibodies to cardiolipin, phosphatidic acid, phosphatidylinositol, and phosphatidylserine in systemic lupus erythematosus: prospective analysis of a series of 92 patients. Clin Exp Rheumatol 1997:15:143-9.

8 Bertolaccini ML, Roch B, Amengual O, Atsumi T, Khamashta MA, Huges GRV. Multiple antiphospholipid tests do not increase the diagnostic yield in antiphospholipid syndrome. BrJ Rheumatol 1998;37:1229-32.

9 Vayssairat M, Abuaf N, Baudot N, Deschamps A, Gaitz JP. Abnormal $\lg G$ cardiolipin antibody titers in patients with Raynaud's phenomenon and/or related disorders: prevalence and clinical significance. J Am Acad Dermatol 1998;38:555-8.

10 Naldi L, Locati F, Marchesi L, Cortelazzo S, Finazzi G, Galli M, et al. Cutaneous manifestations associated with antiphospholipid antibodies in patients with suspected primary antiphospholipid syndrome: a patients with suspected primary antiphospholipid syndrom

11 Merkel PA, Chang Y, Pierangeli SS, Convery K, Harris EN, Polisson RP. The prevalence and clinical associations of anticardiolipin antibodies in a large inception cohort of patients with connective tissue diseases. Am J Med 1996;101:576-83.

12 Knapik-Kordecka M, Wysokinski WE. Clinical spectrum of Raynaud's phenomenon in patients referred to vascular clinic.Cardiovasc Surg 2000:8:457-62.

13 Bongard O, Bounameaux H, Miescher PA, De Moerloose P. Association of cardiolipin antibodies and abnormal nailfold capillaroscopy in patients with systemic lupus erythematosus. Lupus 1995;4:142-4.

14 Tan EM, Cohen AS, Fries JF, Masi AT, McShane DJ, Rothfield NF, et al. The 1982 revised criteria for the classification of systemic lupus erythematosus. Arthritis Rheum 1982;25:1271-7.

15 Hochberg MC. Updating the American College of Rheumatology revised criteria for the classification of systemic lupus erythematosus. Arthritis Rheum 1997;40:1725. 